Institute of $\mathbf{F}_{\text {ood and }} \mathbf{A}_{\text {gricultural }} \mathbf{S}_{\text {ciences }}$

\title{
Formosan Subterranean Termite, Coptotermes formosanus Shiraki (Insecta: Isoptera: Rhinotermitidae) ${ }^{1}$
}

\author{
Nan-Yao Su and Rudolf H. Scheffrahn²

\section{Introduction}

The genus Coptotermes contains the largest number of termite pests ( 28 species) among the $>2,500$ termite species worldwide, and the Formosan subterranean termite, Coptotermes formosanus, is the most widely distributed and most economically important. The Formosan subterranean termite (FST) acquired its name because it was first described in Taiwan in the early $1900 \mathrm{~s}$, but $C$. formosanus is probably endemic to southern China. This destructive species was apparently transported to Japan prior to the 1600s and to Hawaii in the late 1800s (Su and Tamashiro 1987). By the1950s, it was reported in South Africa and Sri Lanka. During the 1960s it was found in Texas, Louisiana, and South Carolina. In 1980, a well-established colony was thriving in a condominium in Hallandale, Florida. A single colony of FST may contain several million termites (versus several hundred thousand termites for native subterranean termite species) that forage up to $300 \mathrm{ft}$ in soil (Figure 1). Because of its population size and foraging range, the presence of FST colonies pose serious threats to nearby structures. Once established, FST has never been eradicated from an area.

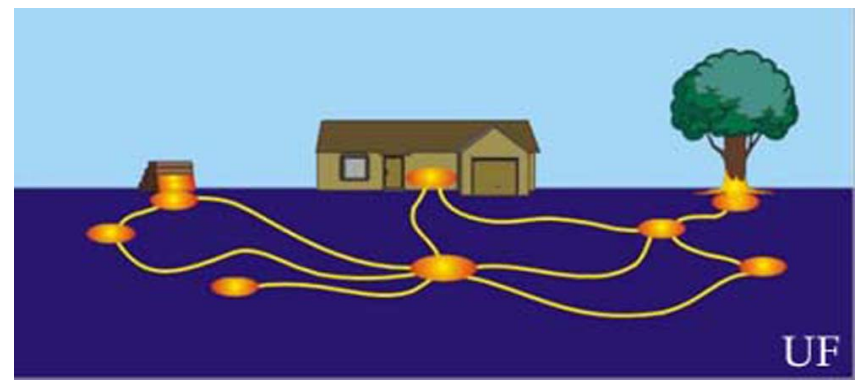

Figure 1. A single colony of the Formosan subterranean termite, Coptotermes formosanus Shiraki, may contain several million individuals that forage up to $300 \mathrm{ft}$ in soil. Credits: Nan-Yao Su, University of Florida

\section{Distribution}

As of 2000, the distribution of FST in the United States includes Alabama, California (an isolated infestation in San Diego County), Florida, Georgia, Hawaii, Louisiana, Mississippi, North and South Carolina, Tennessee, and Texas (Figure 2).

1. This document is EENY-121 one of a series of Featured Creatures from the Entomology and Nematology Department, Florida Cooperative Extension Service, Institute of Food and Agricultural Sciences, University of Florida. Published: January 2000. Revised: May 2000. This document is also available on Featured Creatures Website at http://creatures.ifas.ufl.edu. Please visit the EDIS Website at http://edis.ifas.ufl.edu. Additional information on these organisms, including many color photographs, is available at the Entomology and Nematology Department website at http://entnemdept.ifas.ufl.edu/.

2. Nan-Yao Su, professor and Rudolf H. Scheffrahn, professor, Entomology and Nematology Department, Ft. Lauderdale REC, University of Florida, Ft. Lauderdale, FL. 


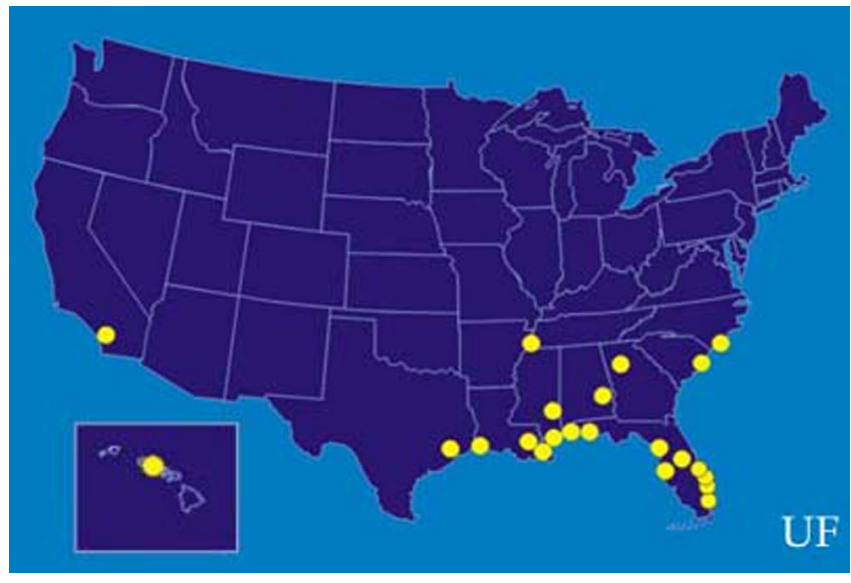

Figure 2. Distribution of the Formosan subterranean termite, Coptotermes formosanus Shiraki, in the United States. Credits: Nan-Yao Su, University of Florida

The FST was first reported in Florida in early 1980s in Hallandale, Broward County. But it was probably introduced there at least five to 10 years previously. By 1985, it was found in Orlando and the Pensacola area. In 1991, well-established infestations were discovered in Tampa, Hillsborough County. In 1996, C. formosanus was collected in North Palm Beach of Palm Beach County. Additional infestations have been confirmed in Jensen Beach, Martin County in 1998, Jupiter, Palm Beach County and Crystal River of Citrus County in 1999, and Tallahassee, Leon County in 2000. In urban southeastern Florida where the FST was first found, its distribution has expanded to include areas from North Miami Beach, Dade County to Ft. Lauderdale of Broward County (Figure 3).

\section{Description and Identification}

As its name indicates, the Formosan subterranean termite is a subterranean termite species characterized by large populations that share interconnected foraging galleries in soil. When these termites invade a house above-ground, foraging tubes of ca. 0.25 to 0.5 inch diameter may be found connecting soil tubes and the infested house (Figure 4).

As with other termite species, colonies of FST contain three primary castes: the reproductives (e.g. king, queen, alates or swarmers, and immature alates or nymphs), soldiers, and workers. The majority of the nestmates are workers that are responsible for acquisition of nutrients, i.e. cellulose in wood. Alates

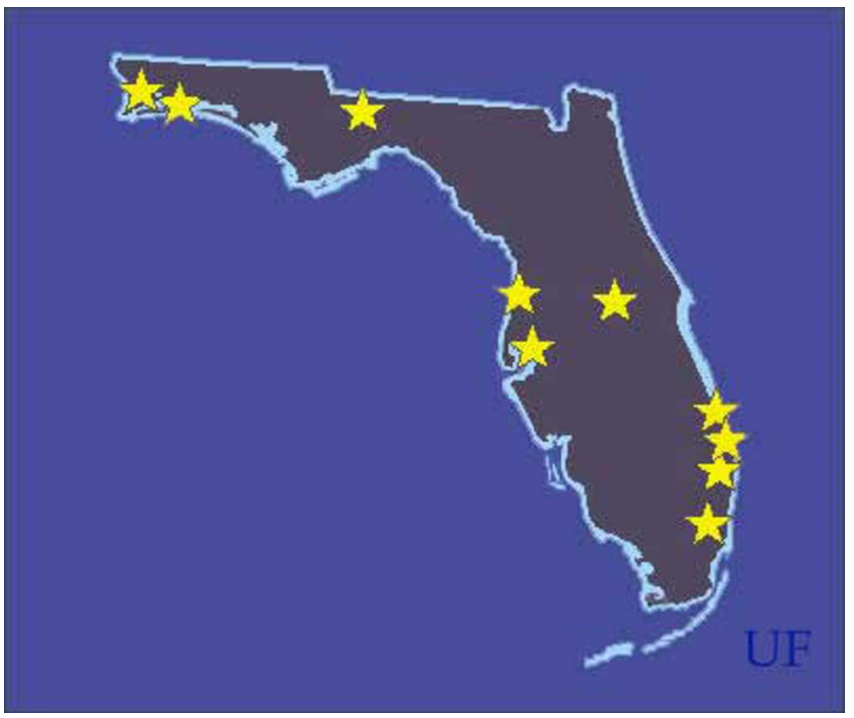

Figure 3. Distribution of the Formosan subterranean termite, Coptotermes formosanus Shiraki, in Florida. Credits: Nan-Yao Su, University of Florida

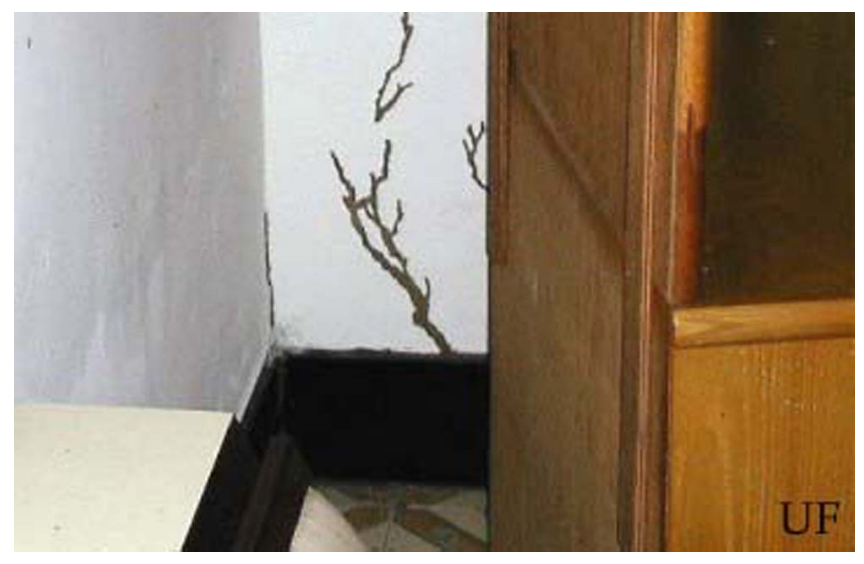

Figure 4. Soil tubes of the Formosan subterranean termite, Coptotermes formosanus Shiraki. Credits: Nan-Yao Su, University of Florida

and soldiers are most useful for identification (Scheffrahn and Su 1994).

Alates of FST are yellowish-brown and 12 to 15 $\mathrm{mm}$ long ( 0.5 to $0.6 \mathrm{inch})$. There are numerous small hairs on the wings of these comparatively large swarmers. Dispersal flights or "swarms" are massive and begin at dusk on calm and humid evenings from April to July. Alates are attracted to lights, so they are usually found near windows, light fixtures, window sills, and spider webs around well lighted areas (Figure 5).

Soldiers of FST have an orange-brown, oval-shaped head, curved mandibles and a whitish body (Figure 6). When disturbed, soldiers readily 


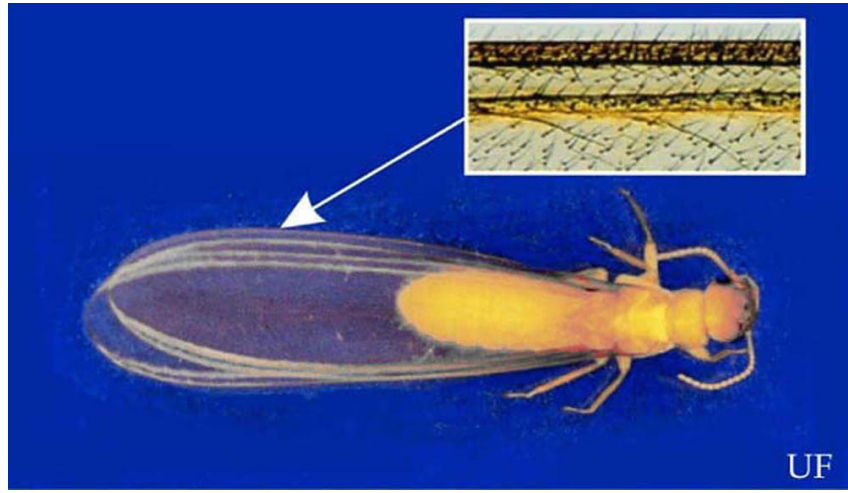

Figure 5. Small hairs on wings of swarmers of the Formosan subterranean termite, Coptotermes formosanus Shiraki. Credits: Nan-Yao Su, University of Florida

attack any approaching objects, and may secrete a white gluey fluid (called defensive secretion) from a large opening (called fontanel) in the head. There are more soldiers ( 10 to $15 \%$ ) in a FST colony than that of the native subterranean species in Florida (1 to $2 \%$ ). Because the FST colony contains a larger soldier proportion than native subterranean termites, infestations with many soldiers is a clue to its presence.

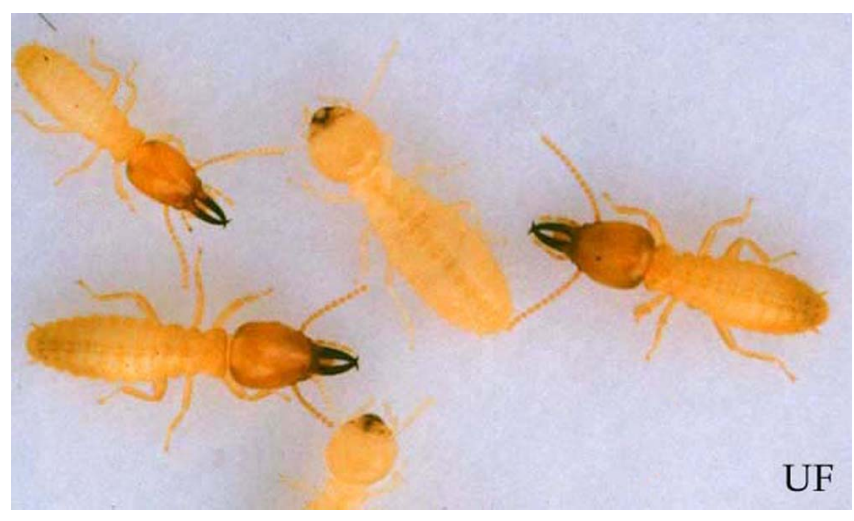

Figure 6. soldiers (orange-brown, oval-shaped head) and workers of the Formosan subterranean termite, Coptotermes formosanus Shiraki. Credits: Nan-Yao Su, University of Florida

\section{Life History}

A single colony of $C$. formosanus may produce over 70,000 alates. After a brief flight, alates shed their wings. Females immediately search for nesting sites with males following closely behind. When the pair find a moist crevice with wooden materials, they form the royal chamber and lay approximately 15 to 30 eggs. Within two to four weeks, young termites hatched from the eggs. The reproductives nurse the first group of young termites until they reach third instar (Figure 7). One to two months later, the queen lay the second batch eggs which would be eventually nursed by termites from the first egg batch. It may take three to five years before a colony reach substantial number to cause severe damage and produce alates.

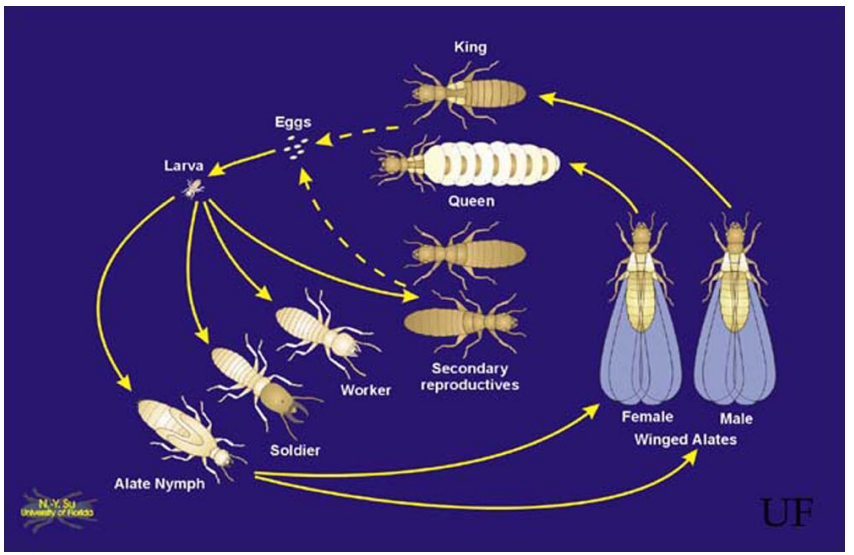

Figure 7. Life cycle of the Formosan subterranean termite, Coptotermes formosanus Shiraki. Credits: Nan-Yao Su, University of Florida

\section{Damage}

A single individual of the FST doesn't consume more wood than a single native subterranean termite, however, because of its large population size, a FST colony can cause more structural damage in a shorter time. Wood products that are infested by FST may be recognized by tapping the wood with a hard object. In severe infestations, FST hollows out woods leaving a paper-thin surface. A hollowed wood surface may look blistered or peeled (Figure 8).

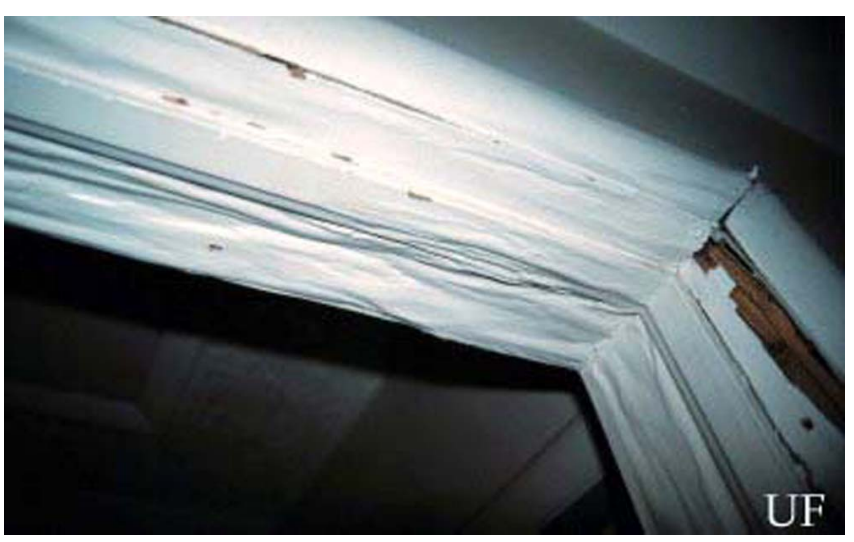

Figure 8. Blistered wood surface damage caused by the Formosan subterranean termite, Coptotermes formosanus Shiraki. Credits: Nan-Yao Su, University of Florida 
Another characteristic of FST is carton nest material that is made of termite excrements, chewed wood, and soil. Carton nests (Figure 9) are usually found in structure voids such as between walls and beneath sinks.

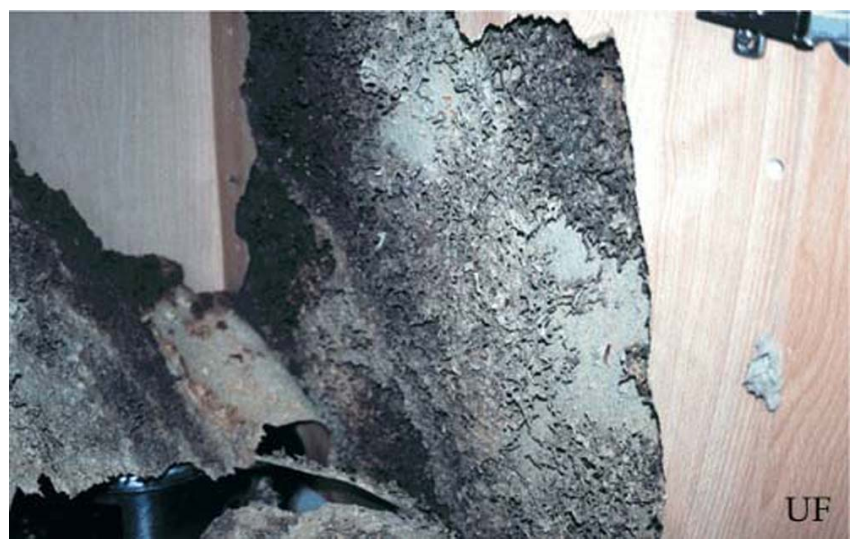

Figure 9. Carton nest of the Formosan subterranean termite, Coptotermes formosanus Shiraki. Credits: Nan-Yao Su, University of Florida

The FST generally invades structures from the ground. They commonly enter through expansion joints, cracks and utility conduits in slabs. Any wood-to-ground contact is an inviting entrance for FST infestations. In some occasions, however, FST can form colonies that are not connected to ground, called aerial colonies. If a pair of alates successfully finds suitable conditions, i.e. adequate food and moisture sources in a building, they can initiate a colony with no ground connection. The flat roofs of high rise buildings, because they always pool rain water, are ideal places for the FST to initiate aerial infestations if portals of entry are found. Our survey data indicated that more than $25 \%$ of the infestations found in the urban southeastern Florida are caused by aerial colonies (Su and Scheffrahn 1987).

Studies also found that FST attack many species of living plants. The FST attacks structural lumbers and living plants because they are sources of cellulose. However, this termite is also known to attack non-cellulose materials such as plaster, plastic, asphalt, and thin sheets of soft metal (lead or copper) in search of food and moisture. Their highly publicized ability to penetrate solid concrete is a fallacy. However, the FST is persistent in finding small cracks in concrete which they enlarge and use as foraging routes.

\section{Pest Status}

Although their distribution in the United States is more restricted than other subterranean termites such as Reticulitermes species, $C$. formosanus can cause substantial economic loss in infested areas. In the city of New Orleans where this termite species was introduced in the 1950's, the control and repair costs due to FST is estimated at $\$ 300$ million annually (Suszkiw 1998). It is considered the single most economically important insect pest in the state of Hawaii. As the populations grow, economic loss caused by this termite species in more recently established areas will approach the pest status experienced in New Orleans and Hawaii.

\section{Management}

\section{Preventive Practice}

Wood pressure-treated with preservatives (creosote, pentachlorophenol, inorganic salts such as chromated copper arsenate or CCA, etc.) are required by building codes for use at the point of wood-soil interface; primarily to prevent fungi decay. The FST does not damage pressure-treated wood but is capable of by-passing the treated wood to infest untreated wood in structures. The combination of water and wood or other cellulose materials provide attractive conditions for the FST. Leaky plumbing, air conditioning condensate, and any portion of the building that may collect excessive amounts of moisture should be corrected to maintain an environment less attractive to FST.

\section{Soil Treatment}

Conventional method for control of subterranean termites, including the FST is to place a chemical barrier between termites and the structure to be protected (Figure 10A). Currently available termiticides include chlorpyrifos (Dursban ${ }^{\circledR} \mathrm{TC}$, Equity ${ }^{\circledR}$, Empire $\left.{ }^{\circledR}\right)$, permethrin (Dragnet ${ }^{\circledR}$ FT, Prelude ${ }^{\circledR}$ ), cypermethrin (Prevail® FT, Demon ${ }^{\circledR}$ TC), bifenthrin (Biflex ${ }^{\circledR}$ FT), fevalerate (Tribute $\left.{ }^{\circledR}\right)$, imidachloprid (Premise $\left.{ }^{\circledR}\right)$ and fipronil (Termidor $\left.{ }^{\circledR}\right)$. Pyrethroids such as permethrin, cypermethrin, bifenthrin and fenvalerate repel termites from treatment barriers, while other termiticides prevent termite invasion by lethal contact. For 
preconstruction treatment, soil termiticides are applied onto sub- slab soil before the foundation is poured. Post-construction treatment can be done by drilling holes through slabs and injecting insecticides under foundation and by drenching trenches dug in soil along building foundations.

\section{Population Control Using Baits}

Because of the large size of a FST colony, application of soil termiticides beneath a structure may not impact the overall population of several million termites that inhabit galleries extending up to $300 \mathrm{ft}$ (Figure 10A). In recent years, baits have become available to control FST populations near a structure. One such approach is the monitoring-baiting program that incorporated a bait matrix containing a chitin synthesis inhibitor, hexaflumuron, commercially known as the Sentricon ${ }^{\circledR}$ Termite Colony Elimination System. Stations containing a monitoring device are first installed in soil surrounding a home (Figure 10B). When termites are found in the station, the monitoring device is replaced with a tube containing the hexaflumuron-laced bait. Termites feeding in the stations then carry baits to other members of a colony, leading to the demise of entire colony population (Figure 10C).

Details of the monitoring-baiting procedure can be found at http://www.ftld.ufl.edu/termite97.htm. Field trials using hexaflumuron baits repeatedly demonstrated that baited FST colonies could be eliminated (Grace et al. 1996, Su and Scheffrahn 1998). Other baits (active ingredients) currently available include FirstLine ${ }^{\circledR}$ (sulfluramid), Exterra ${ }^{\circledR}$ (diflubenzuron), and Terminate ${ }^{\circledR}$ (sulfluramid). With the exception of Terminate that can be purchased by individual homeowners, all baits are to be applied by trained pest control professionals. Efficacy and claims of these commercial bait products may differ from one another. It is prudent to read the fine print and ask questions. For a review of some bait products, please refer to:

http://www.uky.edu/Agriculture/Entomology/entfacts/ struct/ef639.htm.

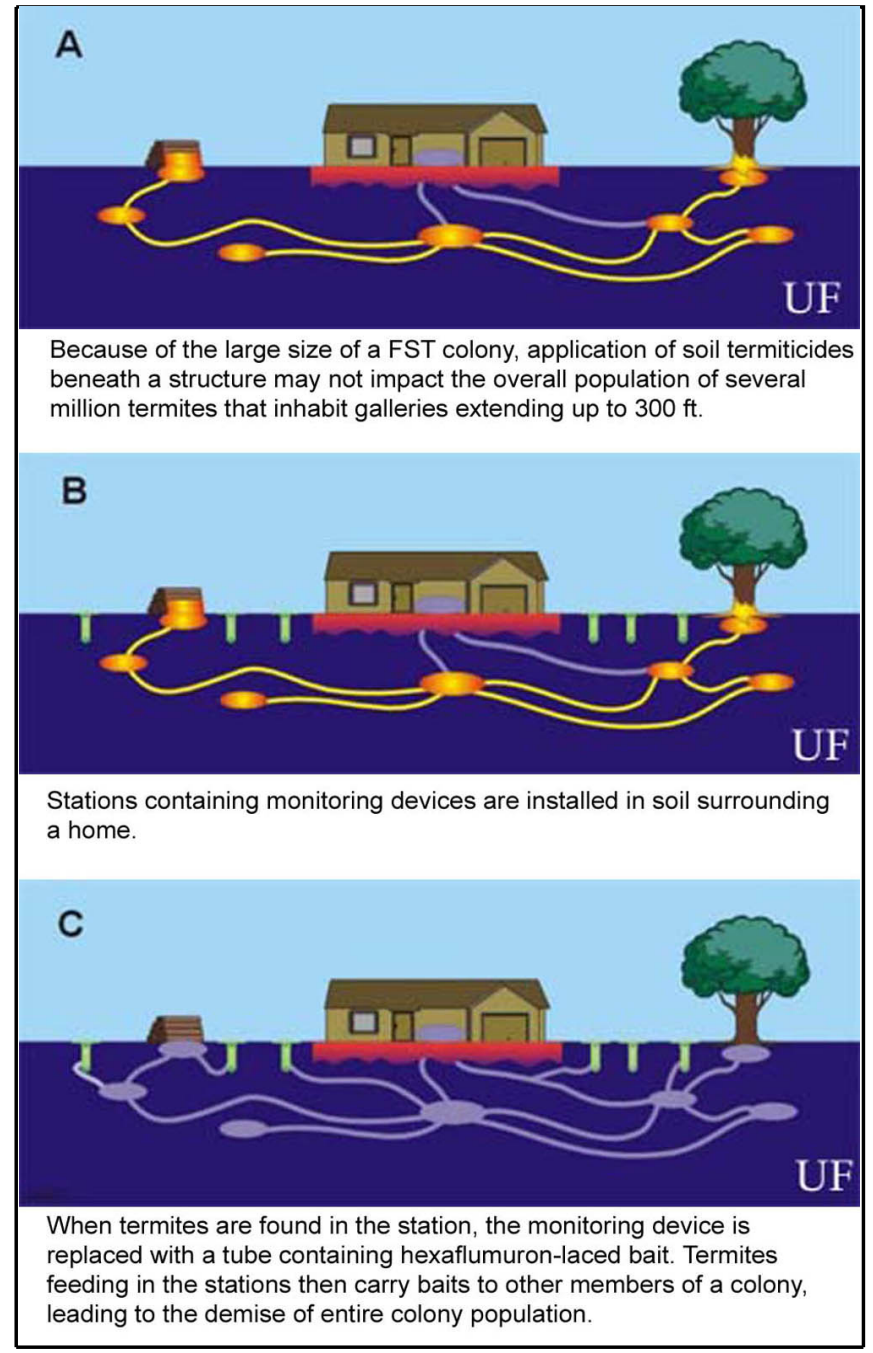

Figure 10. Different control techniques for the Formosan subterranean termite, Coptotermes formosanus Shiraki. Credits: Nan-Yao Su, University of Florida

\section{Selected References}

Grace, J.K., C.H.M. Tome, T.G. Shelton, and R.J. Oshiro. 1996. Baiting studies and considerations with Coptotermes formosanus (Isoptera: Rhinotermitidae) in Hawaii. Sociobiology 28: 511-520.

Scheffrahn, R.H., and N.-Y. Su. 1994. Keys to soldier and winged adult termites (Isoptera) of Florida. Fla. Entomol. 77: 460-474.

Su, N.-Y., and R.H. Scheffrahn. 1987. Current status of the Formosan subterranean termite in Florida, pp. 27-31. In: M. Tamashiro and N.-Y. Su [eds.], Biology and control of the Formosan subterranean termite. College of Trop. Agr. Human Resources, Univ. of Hawaii, Honolulu, HI. 
Su, N.-Y., and R. H. Scheffrahn. 1998. A review

of subterranean termite control practices and

prospects for integrated pest management programs.

Integrated Pest Management Reviews 3: 1- 13.

Su, N.-Y., and M. Tamashiro. 1987. An

overview of the Formosan subterranean termite in the world, pp. 3-15. In: M. Tamashiro and N.-Y. Su

[eds.], Biology and control of the Formosan

subterranean termite. College of Trop. Agr. Human

Resources, Univ. of Hawaii, Honolulu, HI.

Suszkiw, J. 1998. The Formosan termite: A

formidable foe. Agricultural Research 46: 4-9. 